\title{
THE REMOVAL OF HEAVY METAL (NICKEL) IONS FROM WASTE WATERS
}

\author{
T. Obushenko, N. Tolstopalova, O. Bolielyi
}

\author{
National Technical University of Ukraine «Igor Sikorsky Polytechnic Institute», Kyiv \\ e-mail: tio63@mail.ru
}

\begin{abstract}
Solvent sublation is a combined method that includes advantages of ionic flotation and liquid extraction. This is a process in which flotation product (sublate) concentrates in a thin layer of organic liquid, which is located on the surface of aqueous phase. There are only a few scattered and unsystematic researches of solvent sublation for water treatment from heavy metal ions. However, such feature of solvent sublation as possibility of metal ions concentration in little volumes of organic solvent independently from distribution coefficient indicates perspective of this method for the treatment of waste waters polluted by heavy metals with the opportunity of metal regeneration. Solvent sublation of nickel ions from low concentrated $(20 \mathrm{mg} / \mathrm{dm} 3)$ aqueous solutions with the use of sodium dodecylsulphate as anionic surfactant was studied. It was discovered, that branched alcohols are better at retention of sublate than those unbranched. Thus, isoamyl alcohol is more effective for solvent sublation than pentanol. Dependences of removal ratio on $\mathrm{pH}$ of environment, on molar ratio of $\mathrm{Ni2}+$ :surfactant were researched. The required volume of organic phase was determined.

The research of nickel ions removal by solvent sublation from model solutions allowed to determine rational conditions of the process: $p H$ 9, molar ratio of Ni2+:surfactant $=1: 2$, volume of organic phase $5 \mathrm{~cm} 3$. Under these conditions removal ratio of nickel ions into isoamyl alcohol is $95,8 \%$.
\end{abstract}

Key words: nickel, solvent sublation, removal ratio, sodium dodecylsulphate, sublat.

\section{Introduction}

Among the widely-spread methods of waste water treatment from toxic metals there are flotation and extraction. Extraction is effective, when concentration of toxic compounds is above 1 $\mathrm{g} / \mathrm{dm}^{3}$ and acidity of aqueous phase is high. There is no purpose to use extraction when metals extract from more dissolved solutions because of higher consumption of valuable extragents. Ionic flotation is also highly productive and effective in processing of low concentrated solutions, however in this case, there are usually pollution of foam product by treated solution and contaminants. Solvent sublation is a combination of ionic flotation and solvent extraction, which contains advantages of both methods. Solvent sublation is known as flotation process, during which floated compound (sublate) concentrates in a thin layer of liquid that doesn't dissolve in water and locates on the surface of aqueous phase [1-3]. Unlike the common aqueous extraction in this process mass transfers from aqueous to organic phase with the gas bubbles participation. Process is carried out with a little consumption of gas that doesn't destroy upper layer of organic liquid. Sublate can dissolve on the surface of liquid as well as create suspended solids, which maintains because of wetting. Although primarily solvent sublation was suggested for extraction of metal ions by using surface active compounds. Subsequently this process was realized in other cases: extraction of soluble organic compounds based on their surface activity, flotation of sediment and hydrophobic liquids. Nowadays solvent sublation as a method of separation and concentration finds 
its application in waste water treatment from organic and inorganic contaminants that contain in dissolved form and as compounds which are insoluble in water (liquids and solid compounds), also in analytical chemistry as the way of quantitative metal trace and surface-active compounds determination [4-7]. Primarily it was supposed that advantage of solvent sublation over common ionic flotation is only in the lack of foam. However, nowadays there are also next advantages such as a possibility of work with large volumes of water objects, concentration of which can easily exceed proportion of 100:1 that allows to use solvent sublation for extraction of analyzed compounds (metal ions, surface-active compounds) in micro- and nano- quantities for analytical aims; active compound is extracted by gas bubbles and enters higher layer of hydrophobic liquid without phase mixing. Thus, separation process provides higher selectivity that potentially higher than other flotation processes. Besides, equilibrium process of compound transferring is typical for extraction while for solvent sublation it is only possible on phase separation boundary but not in volume. It means that solvent sublation process is nonequilibrium and doesn't limit by distribution constant. Therefore, extraction of elements in minor amounts can reach $100 \%$ in theory. In many cases compound that extracts is concentrated in organic phase that significantly ease its further extraction.

Despite all obvious advantages of solvent sublation this method nowadays doesn't find broad industrial application there are many experimental researches, which establish rational parameters of process and new areas of its application [8].

There are only few researches in solvent sublation application for waste water treatment from heavy metal ions and their character is scattered and unsystematic. However, this feature of solvent sublation as a possibility of multiple metal ions concentration in little volumes of organic solvent regardless distribution coefficient points on perspectives of this method for waste water treatment polluted with heavy metals with the aim of their further regeneration.

\section{Experimental}

Solvent sublation of nickel ions from low concentrated $\left(20 \mathrm{mg} / \mathrm{dm}^{3}\right)$ aqueous solutions were studied. To research the solvent sublation process installation and methods, which are described in our work were used [2]. Process was carried out to constant residual concentration of nickel ions, which were determined by standard methods with the use of scanning spectrophotometer Portlab 501. The measure of $\mathrm{pH}$ was controlled by $\mathrm{pH}-$ meter Portlab 102.

Selection of collector in industrial use of ionic flotation special case of which is solvent sublation based on neutralization of cation or anion charge by appropriate ionic surface-active substance i.e. for cation flotation anionic surface-active substances are used and for anion flotation - cationic when necessary. It's important for collector to have ability of forming hardly soluble hydrophobic compounds (sublate) with metal. Dodecyl sulfate is a surface-sactive substance of ionic type, which was used in this work.

Selection of extragent is usually done experimentally. It is known, that necessary properties of solvent must be some polarity, have low solubility in water, density about $0,75-0,90 \mathrm{~g} / \mathrm{cm}^{3}$, it mustn't flow at room temperature, sublate accumulation ability must be at maximum. In general case, effectiveness of process as higher as higher solubility of complex in solvent. In our researches the best results were acquired with higher alcohols. As shown on figure 1 extension of alkali chain increases the effectiveness of solvent sublation for all alcohols that were used (except decanol) and correlates with their density. Density increase leads to increase of extraction ratio. Higher foam forming, low extraction ratio and emulsion forming, which is unwanted effect were discovered while using decanol. 
Besides, it was discovered, that branched alcohols hold sublate better than unbranched. So isoamyl alcohol is more effective for solvent sublation than pentanol.

\section{Results and discussion}

Dependence of extraction ratio from environment $\mathrm{pH}$ was researched. In highly acidic environment ( $\mathrm{pH} 2-4)$ nickel exist in aqueous solution mostly in the form of Ni2+ which can't be extracted directly into organic phase (figure 2).

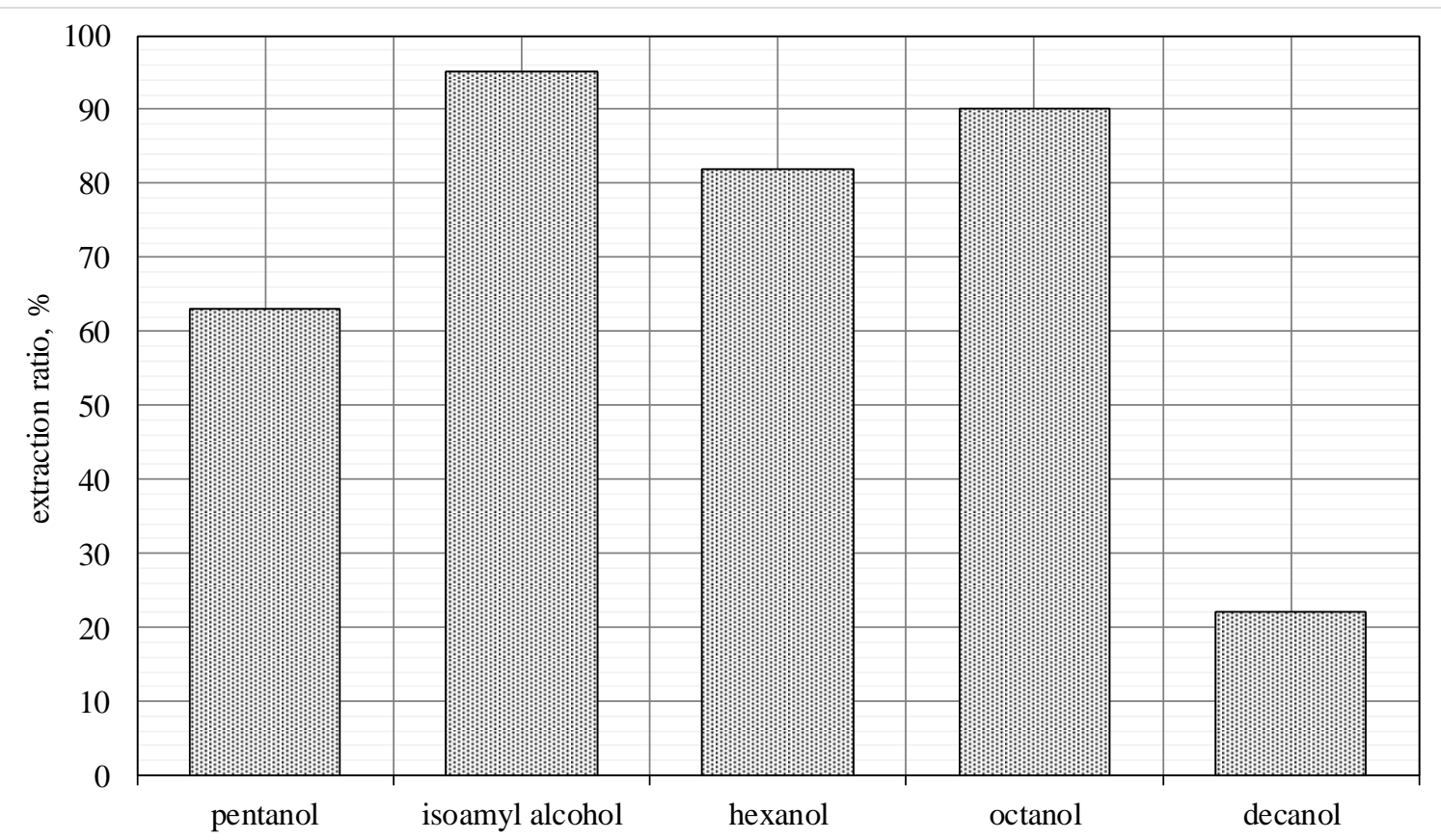

Fig.1 - Effectiveness of nickel ions solvent extraction with different extragents.

Assumed that nickel is removed as medium salts which are formed in aqueous phase by reactions:

$$
\begin{aligned}
\mathrm{Ni}^{2+}+\mathrm{C}_{12} \mathrm{H}_{25} \mathrm{SO}_{4}^{-} & \rightarrow \mathrm{C}_{12} \mathrm{H}_{25} \mathrm{SO}_{4} \mathrm{Ni}^{+} \\
\mathrm{C}_{12} \mathrm{H}_{25} \mathrm{SO}_{4} \mathrm{Ni}^{+}+\mathrm{C}_{12} \mathrm{H}_{25} \mathrm{SO}_{4}^{-} & \rightarrow\left(\mathrm{C}_{12} \mathrm{H}_{25} \mathrm{SO}_{4}\right)_{2} \mathrm{Ni}
\end{aligned}
$$

The yield of medium salt in reaction (2) is unlikely due to dimensional barrier. Extraction ratio of nickel ions increase in $\mathrm{pH}$ range of 5-8 what is explained by formation of $\mathrm{NiOH}^{+}(\mathrm{pH} 5)$, which attaches ions surface-active substance which are adsorbed on surface of gas bubble with the formation of basic salt.

$$
\mathrm{Ni}(\mathrm{OH})^{+}+\mathrm{C}_{12} \mathrm{H}_{25} \mathrm{SO}_{4}^{-} \rightarrow\left(\mathrm{C}_{12} \mathrm{H}_{25} \mathrm{SO}_{4}\right)_{2} \mathrm{Ni}
$$

When $\mathrm{pH}$ equals 9 according to data of potentiometric titration $\mathrm{Ni}(\mathrm{OH})_{2}$ molecules are formed in aqueous phase which adhere to gas bubbles due to adhesion. Thus, the role of surface-active substance is reduced to stabilization of babbles surface and decrease of surface tension on the boundary of phase division solution - organic layer, what eases the conversion of sublate into organic phase. 


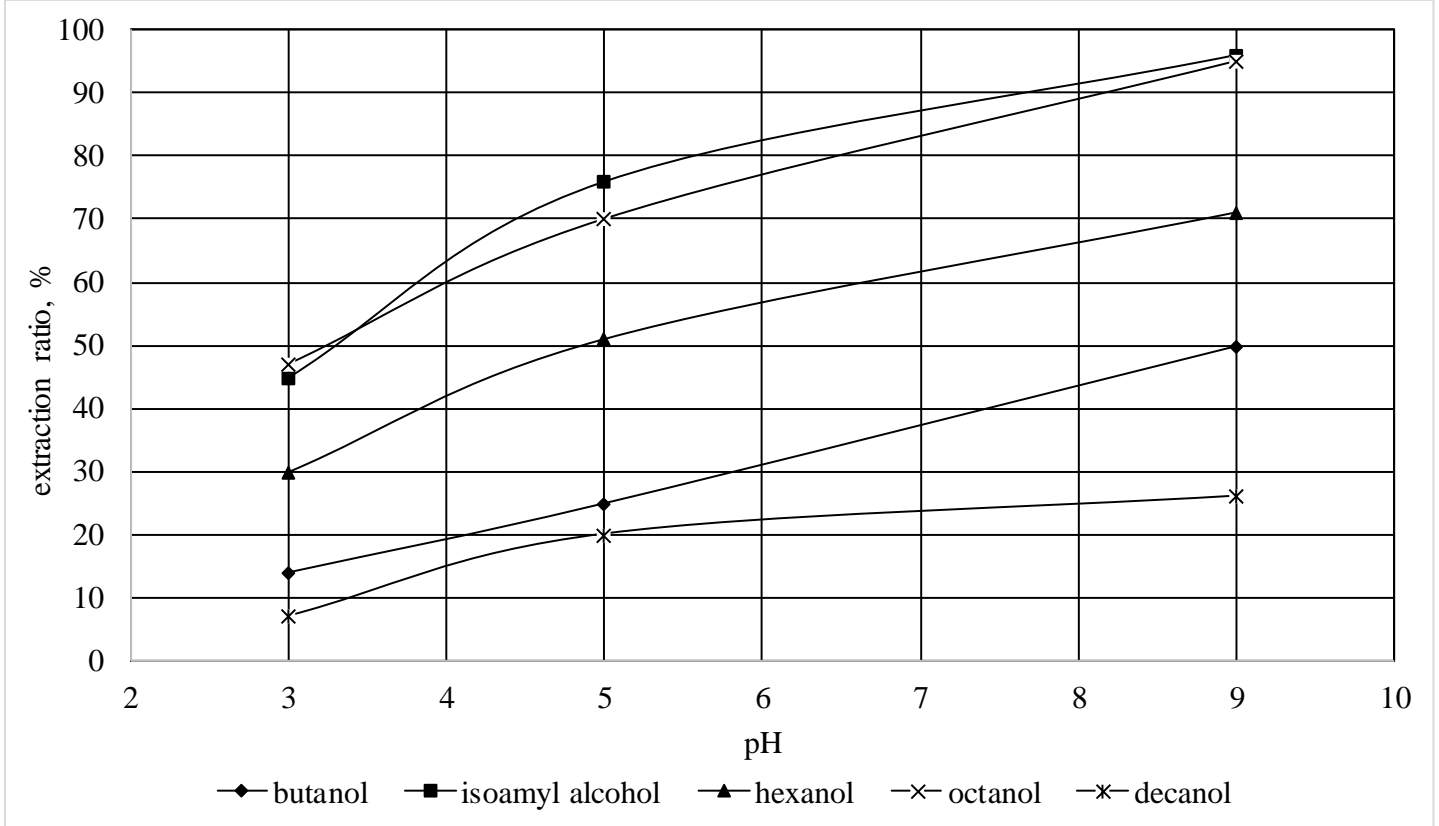

Fig. 2 - Dependence of nickel extraction ratio from solution $\mathrm{pH}$.

Dependence of nickel ions extraction ratio from molar ratio of a surface-active substance: $\mathrm{Ni}^{2+}$ (figure 3) shows, that optimal quantity of surface-active substance, which provide maximum removal of nickel ions $(95,8 \%)$ that corresponds to $\mathrm{Ni}^{2+}$ : surface-active substance $=1: 2$.

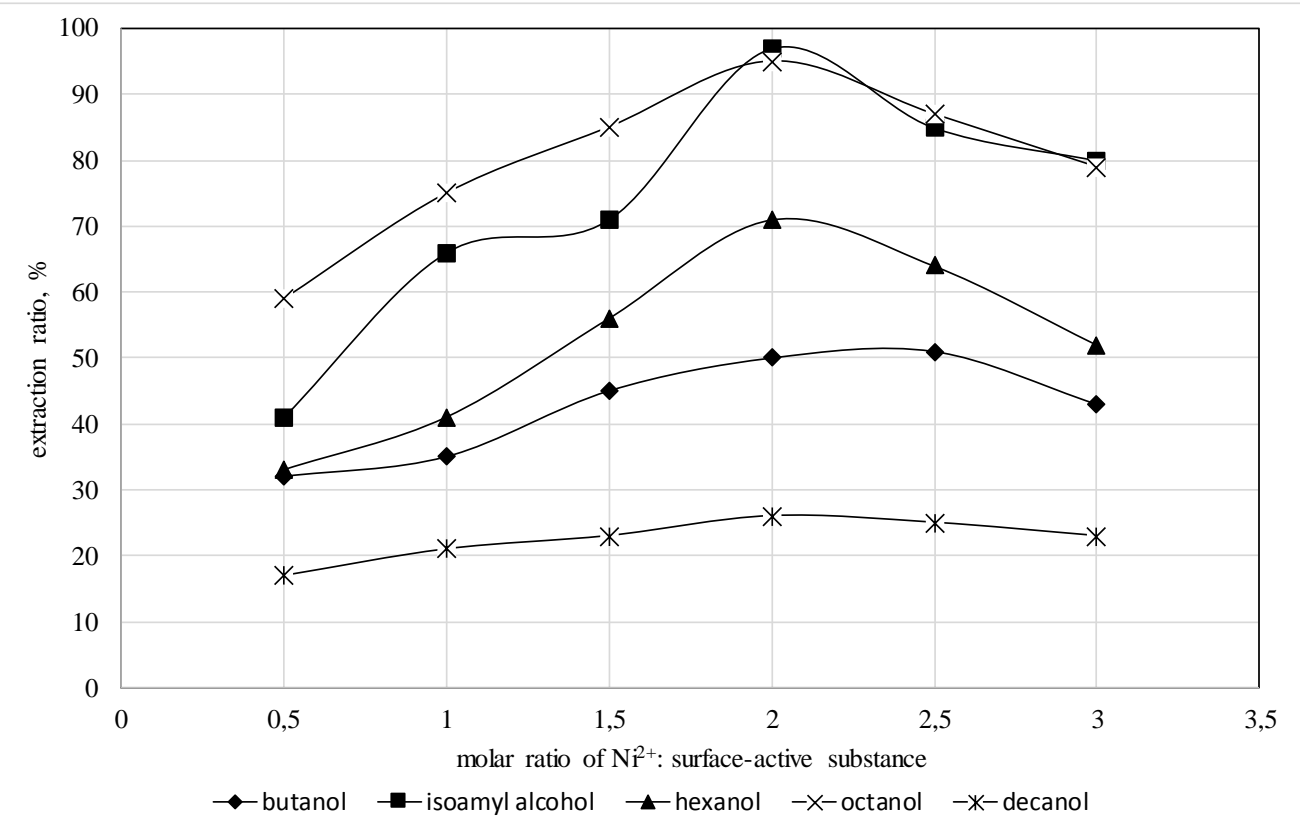

Fig. 3 - Dependence of nickel ions extraction ratio from molar ratio of $\mathrm{Ni}^{2+}$ : surface-active substance.

The volume of organic phase during solvent sublation doesn't affect speed. This is another important advantage of this process over extraction. However, it is important that height of organic layer was enough to ensure integrity. When volume of organic phase has low value, phase 
separation boundary can tear, what leads to loss of process efficiency. Reverse mass transfer of sublate from organic phase into aqueous will begin (figure

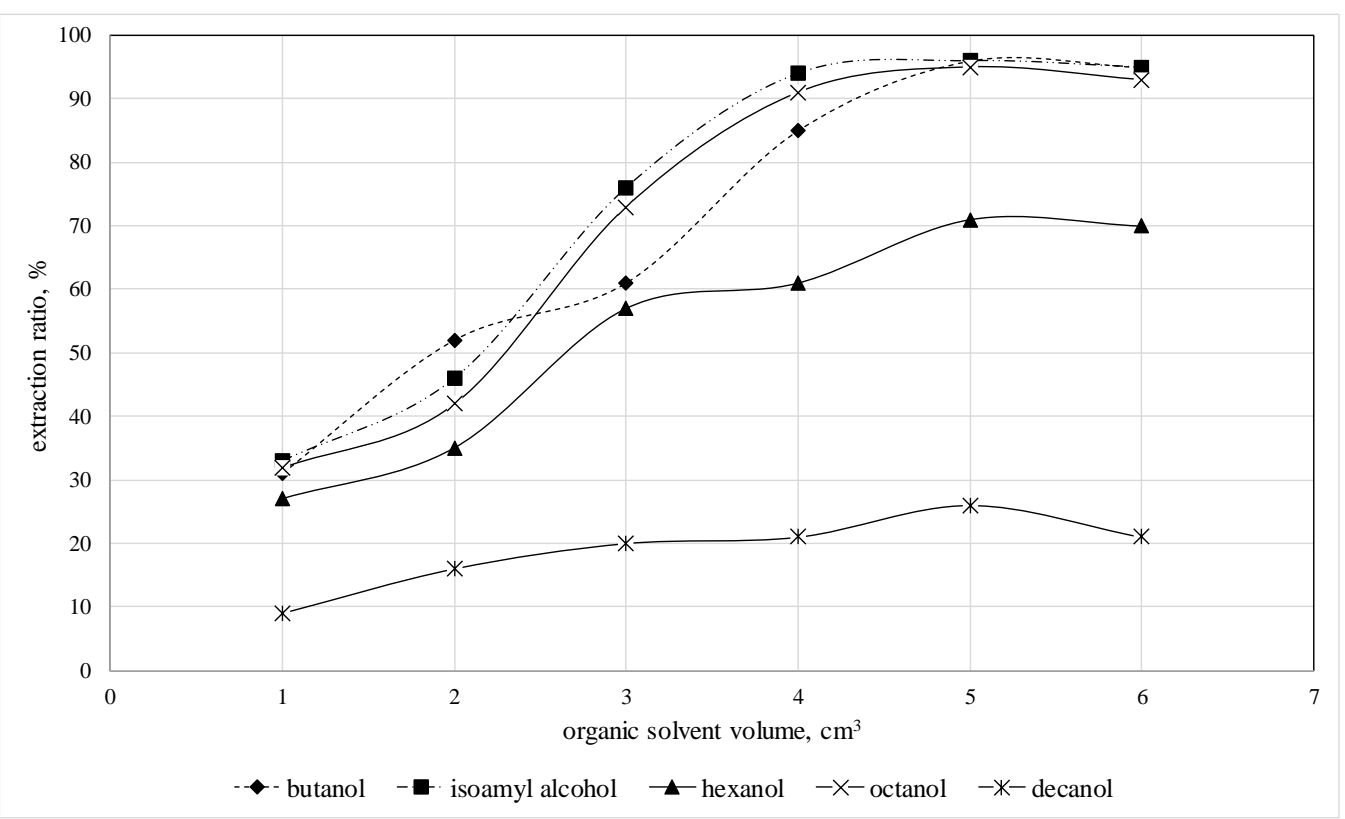

Fig. 4 - Dependence of nickel ions extraction ratio from organic phase.

For effective process flow it is enough of $5 \mathrm{~cm}^{3}$ of isoamyl alcohol. Further increase of organic phase amount doesn't lead to significant change of nickel ions extraction ratio.

\section{Concolusions}

Waste water treatment is a significant issue for chemical technologies. The use of such processes as solvent sublation is less expensive and more effective alternative for treatment of systems, which include hydrophobic compounds with limited solubility. Thus, solvent sublation doesn't require devices for mixing and separation of solutions, which are necessary for extraction processes.

On the other hand, possibility of metal concentration in trace amounts makes solvent sublation quite perspective for their accurate determination in natural or waste waters. Removal and processing of trace metals is a very important aspect for the future creation of water processing schemes, which are practically wasteless.

The researches of $\mathrm{Ni}^{2+}$ solvent sublation from model solutions shows the importance not only in correct choice of surfactant and organic solvent but also in their selection according to each case. The possibility to theoretically predict the presence and character of interaction between surfactant and metal doesn't always exist. Solvent sublation of $\mathrm{Ni}^{2+}$ with the concentration of $20 \mathrm{mg} / \mathrm{dm}^{3}$ in aqueous solutions were researched. It appears, that isoamyl alcohol and octanol show high efficiency during solvent sublation of nickel sublate. Butanol is almost ineffective and it makes difficulties for sampling as it significantly dissolves in water. Decanol is also an ineffective solvent for this process.

Conducted researches of solvent sublation for nickel ions removal from modeling solutions allow to determine the rational conditions of process which are $\mathrm{pH}$ equals to 9 , molar ratio of $\mathrm{Ni}^{2+}$ : surface-active substance is $1: 2$, volume of organic phase equals to $5 \mathrm{~cm}^{3}$. By using this conditions nickel ions removal ratio into isoamyl alcohol was $95,8 \%$. 


\title{
УДАЛЕНИЕ ИОНОВ ТЯЖЕЛЫХ МЕТАЛЛОВ (НИКЕЛЬ) ИЗ СТОЧНИХ ВОД
}

\author{
Т.И. Обушенко, Н.М. Толстопалова, А.С. Болелый
}

Национальный технический университет Украины «Киевский политехнический институт имени Игоря Сикорского»

e-mail: tio63@mail.ru

Флотоэкстракциия - комбинированный метод, сочетающий в себе достоинства ионной флотации и жидкостной экстракции. Это такой процесс, при котором сфлотированное вещество (сублат) концентрируется в тонком слое органической жидкости, находящейся на поверхности водной фазы. Исследования по применению флотоэкстракиии для очистки сточных вод от ионов тяжельх металлов малочисленны $и$ носят разрозненный несистематичный характер. Однако такая особенность флотоэкстракиии, как возможность многократной концентрации ионов металлов 8 небольших объемах органического растворителя вне зависимости от коэффициента распределения, указывает на перспективность этого метода для очистки сточных вод, загрязненных тяжельми металлами, с целью последующей их регенерации. Изучена

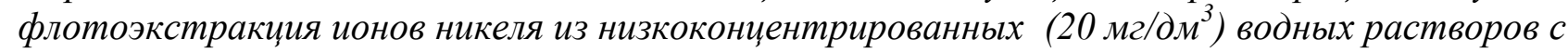
применением анионного ПАВ - додецилсульфата натрия. Было установлено, что разветвленные спирты лучше удерживают сублат, чем неразветвленные. Так изоамиловый спирт более эффективный для флотоэкстракции, чем пентанол. Исследована зависимость степени извлечения ионов никеля от рH среды, от молярного соотношения $\mathrm{Ni}^{2+}$ : ПАВ. Определен необходимый объем органической фазы.

Проведенные исследования флотоэкстракиионного удаления ионов никеля из модельных растворов позволили определить рациональные условия проиесса: рН 9, молярное соотношение $\mathrm{Ni}^{2+}:$ ПАР $=1: 2$, объем органической фазы $5 \mathrm{~cm}^{3}$. При этих условиях степень удаления ионов никеля в изоамиловый спирт составила 95,8\%.

Ключевые слова: никель, флотоэкстракция, степень извлечения, додецилсульфат натрия,сублат.

\section{ВИДАЛЕННЯ ІОНІВ ВАЖКИХ МЕТАЛІВ (НІКЕЛЬ) ІЗ СТІЧНИХ ВОД Т.І. Обушенко, Н.М. Толстопалова, О.С. Болелий}

Національний технічний університет України «Київський політехнічний інститут імени Ігоря Сікорського»

e-mail: tio63@mail.ru

Флотоекстракиія - комбінований метод, щчо включає переваги іонної флотації та рідинної екстракції. Це такий процес, при якому сфлотована речовина (сублат) концентрується у тонкому шарі органічної рідини, щзо знаходиться на поверхні водної фази. Дослідження у застосуванні флотоекстракиії для очищення стічних вод від іонів важких металів малочисельні і носять розрізнений та несистематичний характер. Однак така особливість флотоекстракиії як можливість багатократної концентрації іонів металів $y$ невеликих об'ємах органічного розчинника незалежно від коефіиієнту розподілу, вказує на перспективність ичього методу для очищення стічних вод, забруднених ваљкими металами $з$ 
метою їх подальшої регенерації. Вивчено флотоекстракиію іонів нікелю 3

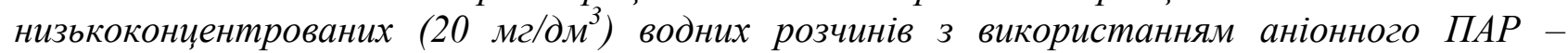
додецилсульфату натрію. Було встановлено, щчо розгалужені спирти краще утримують сублат, ніж нерозгалужені. Так ізоаміловий спирт більш ефективний для флотоекстракції, ніж пентанол. Досліджена залежність ступеню видалення іонів нікелю від рН середовища, від молярного співвідношення $\mathrm{Ni}^{2+}:$ ПАР. Визначено необхідний об'єм органічної фази.

Проведені дослідження флотоекстракиійного видалення ііонів нікелю з модельних розчинів дозволили визначити рачіональні умови процесу: рН 9, молярне співвідношення $\mathrm{Ni}^{2+}:$ ПАР $=1: 2$, об'єм органічної фази $5 \mathrm{~cm}^{3}$. За иих умов ступінь видалення іонів нікелю в ізоаміловий спирт склала 95,85\%.

Ключові слова: нікель, флотоекстракція, ступінь видалення, додецилсульфат натрію, сублат.

\section{References}

1. Kim Y., Shin J., Choi Y., Lee W. Studies on solvent sublation of trace heavy metals by continuous flow system as ternary complexes of 1,10-phenanthroline and thiocyanate ion.//Bulletin of the Korean Chemical Society.— 2003. — № 24. — P.1775-1780.

2. Lu Y., Liu J., Xiong Y., Zhu X. Study of a mathematical model of metal ion complexes in solvent sublation.// Journal of Colloid and Interface Science. — 2003. — № 263. - P. $261-269$.

3. Obushenko T.I., Astrelin I. M., Tolstopalova N. M., Varbanets M. A. and Kondratenko T. A. Wastewater Treatment from Toxic Metals by Flotoextraction // Journal of Water Chemistry and Technology. - 2008. — Vol. 30. — № 4. - P. 241- 245.

4. Obushenko T.I., Astrelin I.M., Tolstopalova N.M., Molodchenko M.€. Zakonomirnosti procesu flotoekstrakciï pri ochishhenni stichnih vod vid ioniv vazhkih metaliv //Naukovi visti NTUU „KPI”. — 2009. - №3. - P.117-122.

5. Obushenko T.I., Astrelin I.M., Tolstopalova N.M., Fedenko Ju.M., Vorozhcov M.A. Doslidzhennja flotoekstrakcijnogo viluchennja ioniv midi zi stichnih vod//Vestnik Nacionalnogo tehnicheskogo universiteta «HPI». — 2010. — №11. - P. $84-94$.

6. Obushenko T.I., Astrelin I.M., Tolstopalova N.M., Kopotun V.P. Flotoekstrakcija ioniv zaliza z nizkokoncentrovanih rozchiniv // Naukovi visti NTUU “KPI”. — 2010. — № 3. - P. 106-111.

7. Bolelyi A.S, Obuchenko T.I, Tolstopalova N.M. Flotoekstraktsiya of nickel ions from aqueous solutions // Young Scientist. — 2017. — №10. — P. 115-118.

8. Astrelin I. M., Obushenko T. I., Tolstopalova N. M., Targonska O. O. Teoretichni zasadi ta praktichne zastosuvannja flotoekstrakciï: ogljad // Voda i vodoochisni tehnologiï. 2013. 一 № 3. - P. 3-23. 